\title{
The Crosstalk between Melatonin and Sex Steroid Hormones
}

\author{
José Cipolla-Neto $^{\mathrm{a}}$ Fernanda Gaspar Amaral $^{\mathrm{b}}$ José Maria Soares, $\mathrm{Jr}^{\mathrm{c}}$ \\ Camila Congentino Gallo ${ }^{b}$ André Furtado $^{d}$ José Eduardo Cavaco ${ }^{d}$ \\ Isabel Gonçalves ${ }^{d}$ Cecília Reis Alves Santos $^{d}$ Telma Quintela ${ }^{d}$
}

aDepartment of Physiology and Biophysics, Institute of Biomedical Sciences, University of São Paulo, São Paulo, Brazil; 'bepartment of Physiology, Federal University of São Paulo, São Paulo, Brazil; 'Laboratório de Ginecologia Estrutural e Molecular (LIM 58), Disciplina de Ginecologia, Departamento de Obstetrícia e Ginecologia, Hospital das Clínicas da Faculdade de Medicina da Universidade de São Paulo, HCFMUSP, São Paulo, Brazil; dCICS-UBI - Health Sciences Research Centre, University of Beira Interior, Covilhã, Portugal

\section{Keywords}

Melatonin · Sex steroid hormones · Reproduction · Placental hormones · Steroidogenesis

\begin{abstract}
Melatonin, an indolamine mainly released from the pineal gland, is associated with many biological functions, namely, the modulation of circadian and seasonal rhythms, sleep inducer, regulator of energy metabolism, antioxidant, and anticarcinogenic. Although several pieces of evidence also recognize the influence of melatonin in the reproductive physiology, the crosstalk between melatonin and sex hormones is not clear. Here, we review the effects of sex differences in the circulating levels of melatonin and update the current knowledge on the link between sex hormones and melatonin. Furthermore, we explore the effects of melatonin on gonadal steroidogenesis and hormonal control in females. The literature review shows that despite the strong evidence that sex differences impact on the circadian profiles of melatonin, reports are still considerably ambiguous, and these differences may arise from several factors, like the use of contraceptive pills, hormonal status, and sleep deprivation. Furthermore, there has been an inconclusive debate about the
\end{abstract}

characteristics of the reciprocal relationship between melatonin and reproductive hormones. In this regard, there is evidence for the role of melatonin in gonadal steroidogenesis brought about by research that shows that melatonin affects multiple transduction pathways that modulate Sertoli cell physiology and consequently spermatogenesis, and also estrogen and progesterone production. From the outcome of our research, it is possible to conclude that understanding the correlation between melatonin and reproductive hormones is crucial for the correction of several complications occurring during pregnancy, like preeclampsia, and for the control of climacteric symptoms.

(c) 2021 S. Karger AG, Basel

\section{Introduction}

Melatonin, $\mathrm{N}$-acetyl-5-methoxytryptamine, is a pleiotropic hormone known to be associated with the modulation of circadian and seasonal rhythms in many biological body functions [1]. This hormone is rhythmically released at night by the pineal gland, and its synthesis is under the control of the endogenous oscillator in the hypothalamic suprachiasmatic nuclei, which, in turn, is syn-
Correspondence to:

Telma Quintela, tquintela@fcsaude.ubi.pt 
chronized with the environmental light/dark cycle [2]. Furthermore, as the timing and interval of the nocturnal melatonin production changes according to the duration of the nights, melatonin secretion is the internal reflection of the external photoperiod [3]. Thus, among other actions, melatonin is known to integrate rhythmic alterations to control circadian and seasonal physiology in several processes such as metabolism, immunity, brain function, and reproduction $[1,4,5]$. Particularly, the role of melatonin in the control of reproductive physiology in photoperiodic, seasonally breading mammals has been documented in the last years. Such control is acquired at the level of hypothalamic pituitary gonadal axis which determines the completion of the reproductive cycle and consequently indicates the best time of the year to breed [6].

Furthermore, when it comes to reproduction, the influence of melatonin in the synthesis and release of the hypothalamic gonadotropin-releasing hormone $(\mathrm{GnRH})$ is well known [3], eventually regulating a variety of physiological responses in gonadal function and activity [7]. However, the first and only review supporting the relationship between melatonin and sex steroid hormones was published in 1999 by Luboshitzky and Lavie [8]. The available data at that time were scarce, and the importance of that relationship was unclear. Here, we review the effects of sex differences and sex hormone background in melatonin circulating levels and update the present knowledge on the crosstalk between sex hormones and melatonin.

\section{Melatonin Synthesis and Function}

Melatonin synthesis involves tryptophan as a precursor that is converted into serotonin after hydroxylation and subsequent decarboxylation. Then, arylalkylamine- $\mathrm{N}$-acetyltransferase (AANAT) $\mathrm{N}$-acetylates serotonin to $\mathrm{N}$-acetylserotonin, which is subsequently converted by hydroxyindole- $O$-methyltransferase to finally produce melatonin. The regulation of melatonin synthesis in the pineal gland is controlled by a multisynaptic neural pathway involving the retinohypothalamic tract and the suprachiasmatic nuclei. The information arrives at the pineal gland via peripheral postganglionic sympathetic fibers [9]. Nocturnal elevations in norepinephrine stimulation, via $\beta$ - and $\alpha 1$-adrenergic receptors in pinealocytes, activate protein kinase $\mathrm{C}(\mathrm{PKC})$ and increases $\mathrm{Ca}^{2+}$ movement, leading to an increase in the intracellular concentration of cyclic adenosine monophosphate
(cAMP). The accumulation of cAMP activates protein kinase A (PKA) which in turn increases AANAT activity [10]. Once synthesized, due to the pineal-cerebrospinal fluid interface, melatonin is directly secreted into the cerebrospinal fluid of the third ventricle and into the blood, reaching all body tissues within a very short period of time [11] (Fig. 1). Even so, the complex regulatory mechanism of melatonin release might not only involve simple diffusion but also carrier-like systems [12].

Melatonin is able to regulate several physiological functions from well-known sleep/wake cycles and modulation of the circadian rhythms to neural development and protection and regulation of the immune system and endocrine functions [13]. Those actions are driven through the activation of $G$ protein-coupled membranebound melatonin receptors MT1 and MT2 and of a putative cytoplasmic melatonin receptor MT3 [14]. Due to the connection between receptors and Gai/o proteins, modulation of the second messenger CAMP and calcium levels and also the activation of PKC subtypes are the most generally accepted signaling transduction pathways triggered by melatonin [15]. Functional membrane melatonin receptors have been described in several brain structures [16] and also in non-neural tissues, such as the cardiovascular system, the immune system, the endocrine system, the gastrointestinal tract, bone, and reproductive organs [17]. In addition, melatonin also exhibits multiple actions through a melatonin-receptor-independent mechanism [18].

\section{Melatonin and Sex Hormones: Bidirectional Communication}

Sex Differences in the Circadian Profiles of Melatonin

One of the first reports of the presence of distinct melatonin profiles between sexes appeared in 1982. The data revealed that the excretion of melatonin in the urine was greater in boys than in girls in the 15-16.9 and 12-14.9 year age-groups, presented no difference in the 11-12.9 year age-group, and was greater in girls than in boys in the 9-10.9 year age-group [19]. Despite these findings of the distinct melatonin profiles between sexes in different age-groups, it became clear that other aspects could also influence melatonin circadian parameters. Several other publications have appeared in recent years documenting some inconsistency regarding the influence of sex on the circadian profiles of melatonin. Earlier onset of salivary melatonin was found in women in comparison with men (19-34 years old) [20]. Similarly, using a constant routine 


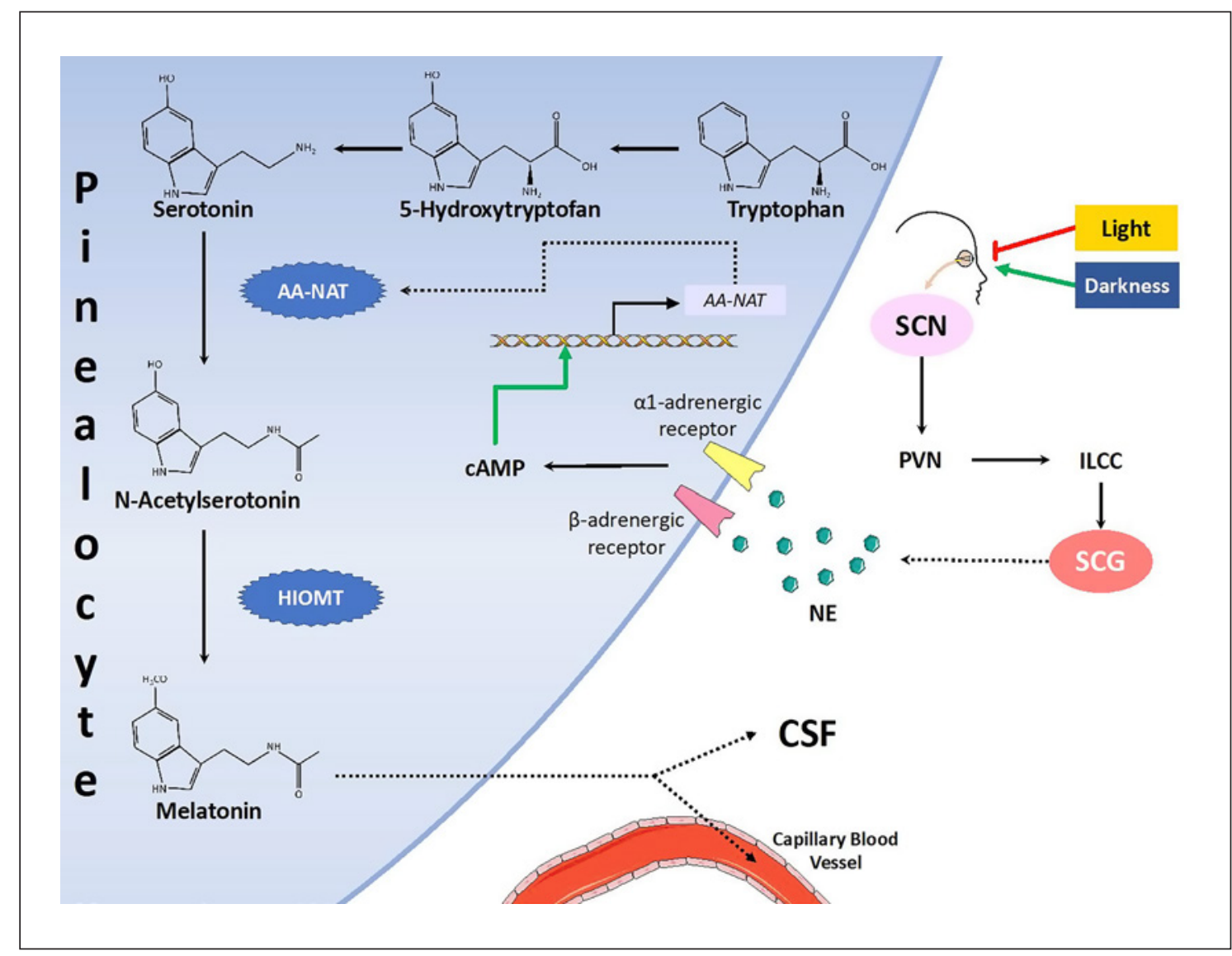

Fig. 1. Melatonin synthesis. This figure summarizes the pathway for melatonin synthesis. The retina receives photic information from the environment. Light has an inhibitory effect, and darkness promotes the transmission of signals from the SCN to the SCG via the PVN followed by the ILCC. The SCG releases NE that binds with $\beta$ - and $\alpha 1$-adrenergic receptors in pinealocytes elevating the intracellular levels of cAMP. cAMP activates AANAT transcription. Serotonin, which is the product of tryptophan's hydroxylation and decarboxylation, is converted to $\mathrm{N}$-acetylserotonin by

protocol to analyze melatonin plasma levels from 28 women and 28 men (18-30 years old), a significantly higher amplitude of melatonin synthesis was observed in women, albeit the presence of similar sleep timing between both sexes [21]. Another noteworthy study, also using a constant routine protocol, determined a possible influence of sex differences in metabolism and excretion of melatonin. The findings indicate that females exhibited a higher amplitude in the rhythm of melatonin plasma levels, but the major melatonin urinary metabolite, 6-sulfatoxymelatonin (aMT6s), levels were not different between groups [22]. A contradictory study in men and women (40-75 years old) showed significantly higher lev-
AANAT and to melatonin by HIOMT. Melatonin is then released by the pineal gland to the cerebrospinal fluid or to the systemic bloodstream via capillary blood vessels. SCN, suprachiasmatic nucleus; SVG, superior cervical ganglion; PVN, paraventricular nucleus; ILCC, intermediolateral cell column; NE, norepinephrine; cAMP, cyclic adenosine monophosphate; AANAT, arylalkylamine- $N$-acetyltransferase; HIOMT, hydroxyindole-O-methyltransferase.

els of aMT6s in females than in males [23]. Finally, other studies did not report any differences in melatonin parameters [24] and in the circadian amplitude of melatonin rhythms between men and women $[25,26]$.

Despite the strong evidence for sex differences in the circadian profiles of melatonin, reports are still considerably ambiguous, and this ambiguity may be attributable to several factors. The influence of hormonal birth control pills might be one cause for the significant variability exhibited in females. Indeed, there is evidence that the use of oral contraceptive pills may increase melatonin levels [27], and several studies do not take into account the female hormonal status. Individual differences in weight, 
age, bedtime, employment status, caffeine uptake, alcohol, medications, contact lenses, sleep deprivation, and methodological differences in melatonin measurement were also associated with the variability observed in melatonin levels. Although the research presented so far overlooked the contribution of sex hormones to melatonin synthesis, the presence of melatonin receptors in human reproductive organs and evidence of reciprocal sex hormone receptors in the pineal gland suggest a relevant crosstalk between sex hormones and melatonin, which will be discussed in the next sections.

\section{Effects of Melatonin on Reproductive Hormones}

Many published reports support a critical role of melatonin on the levels of reproductive hormones, therefore on reproductive activities, through activation of receptors located in the hypothalamic pituitary gonadal axis [28]. Below, we explore the effects of melatonin in the regulation of male and female reproductive hormones and the associated mechanisms of action.

\section{Melatonin Effects on Male Reproductive Hormones}

In men, clinical trials showed no differences in hormonal synthesis of luteotropic hormone (LH), folliclestimulating hormone (FSH), and testosterone after melatonin administration [29-32]. Furthermore, the levels of plasma testosterone, $\mathrm{LH}$, and FSH decreased in prepubertal animals, but were not affected in pubertal and adult male rats, supporting clear age-related changes in melatonin effects [33]. Indeed, the current research is insufficient to draw any firm conclusions about the role of melatonin in the modulation of male reproductive hormones, and future studies should further enhance and confirm these initial findings.

\section{Melatonin Effects on Female Reproductive Hormones}

In opposition to the inconclusive results in men described in the literature, in women, findings indicate a clear response of reproductive hormones to exogenous treatment with melatonin. A report of intravenous administration of melatonin in 3 postmenopausal women was one of the first studies documenting the influence of melatonin in female reproductive hormones, revealing that melatonin decreased the levels of LH [34]. Although showing contradictory results, further reports suggested an important role of melatonin in the modulation of the neuroendocrine-reproductive axis. For example, melatonin treatment enhanced $\mathrm{LH}$ pulse amplitude in women
[35] and LH levels only during the follicular phase [36]. In contradiction, daily melatonin administration during 4 months caused a significant decrease in LH, estradiol, and progesterone [37]. A more recent clinical trial confirmed previous studies by showing a decrease in LH levels only in younger perimenopausal women (43-49 years old). In addition, nocturnal administration of melatonin declined FSH levels [38].

The data gathered from animal experiments clearly corroborated an inhibitory action of melatonin in the synthesis of female gonadal hormones. Melatonin administration to elderly acyclic female rats significantly reduced FSH and LH levels to those observed in cyclic control rats $[39,40]$; however, no differences in estradiol and progesterone levels were detected [40]. The same authors also found that middle-aged melatonin-treated rats presented increased FSH and $\mathrm{LH}$ levels, contradicting the negative influence showed in old rats [40]. More recently, melatonin-treated female rats showed not only a decrease in LH and estradiol levels [7, 41], but also a significant increase in progesterone [41] and dehydroepiandrosterone [42] plasma levels. Overall, despite the different melatonin dosages, time and route of administration, age, and hormonal status, the data yielded by these studies provide convincing evidence of an adjustment of hormones of the female reproductive system by the melatonin.

\section{Mechanisms of Action}

Pineal melatonin secretion regulates $\mathrm{GnRH}$, a central component of the hypothalamic-pituitary-reproductive axis, affecting reproductive hormone secretion [43]. Nonetheless, in the past years, there has been an inconclusive debate about possible binding sites of melatonin for its action on the modulation of reproductive hormone synthesis. Based on currently available evidence, some authors state that melatonin does not seem to act on GnRH neurons [44, 45], while others state that melatonin may act directly on GnRH neurons influencing PKA, PKC, and MAPK pathways [46]. In addition, recent results suggested that melatonin might adjust reproductive hormone levels via an indirect circuitry through the KiSS1/GPR54 system [45, 47]. The consensus view seems to be that melatonin effects on reproductive hormones might be coordinated by 3 different sites of action: (1) the hypothalamic GnRH neurons, (2) the pituitary, and (3) gonads/reproductive organs. Indeed, several theories have been proposed to explain the antiestrogenic action of melatonin in the reproductive system. As reviewed by Cos et al. [48, 49], melatonin reduces the synthesis of bio- 
logically active estrogens through the regulation of the activity of different enzymes involved in the synthesis of steroid hormones on the epithelial mammary cells. Such potential highlights the capacity of melatonin to behave as a selective estrogen enzyme modulator $[48,49]$. Another direct action of melatonin in the regulation of hormone levels is described in cultured granulosa cells, suggesting an upregulation of estradiol after melatonin stimulus [50].

\section{Sex Hormone Modulation of Melatonin Synthesis}

Reproductive hormone receptors are present in the rodent, bovine, and human pineal gland [51-53], suggesting a possible role of reproductive hormones in melatonin synthesis. Indeed, the impact of cyclic oscillations in the levels of sex hormones on pineal melatonin secretion is clear. The effects of male and female reproductive hormones on melatonin synthesis are described in the next sections.

Effects of Male Reproductive Hormones on Melatonin

It is generally accepted that plasma testosterone levels might be indispensable to preserve the nocturnal melatonin peak [54]. Pursuing with clinical trials, it was shown that testosterone treatment of male patients with $\mathrm{GnRH}$ deficiency decreased melatonin to basal levels [55]. In addition, using male pineal cultured glands, it was demonstrated that testosterone significantly increased melatonin release [56]. These previous studies thus can be considered a first step towards a more profound understanding of the role of male reproductive hormones in the regulation of melatonin synthesis.

\section{Effects of Female Reproductive Hormones on Melatonin}

It is well documented that serum melatonin levels decrease with age, attaining minimum levels in menopause [57]. Further, melatonin nocturnal secretion is increased in women using oral contraception [27], and postmenopausal women have diminished nocturnal melatonin levels in comparison with perimenopausal [58]. Clinical trials revealed that administration of estrogens to postmenopausal women suppressed nocturnal melatonin release [59]. In addition, melatonin secretion changed upon administration of GnRH agonists [60]. Delfs et al. [61], on the contrary, argue that circadian melatonin secretion is not regulated by endogenous or exogenous estrogens in women.

Melatonin and Sex Steroids

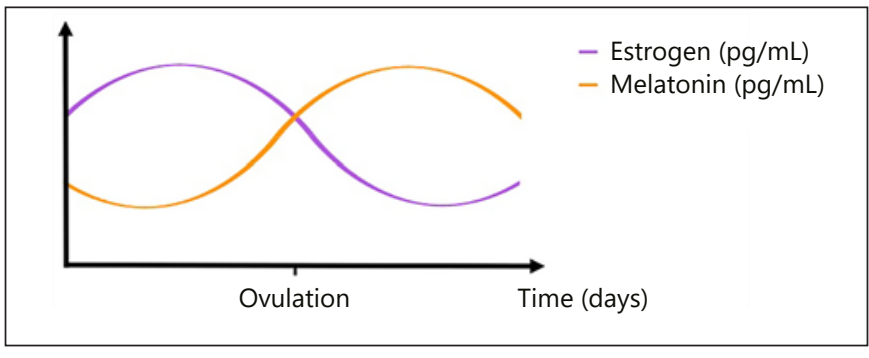

Fig. 2. Reproductive hormones and melatonin circadian rhythms relationship. The variation of reproductive hormone concentration during the menstrual cycle influences melatonin circadian concentration. On the other hand, melatonin variations during the day also influence reproductive hormone concentration along the month.

In addition, the function of female reproductive hormones on melatonin synthesis and secretion also comes from animal studies. Estradiol treatment of rat pineal explants significantly increases melatonin production in vitro [62]. As a rebuttal to the increase of melatonin levels in the presence of estrogens, it was further demonstrated that subcutaneous estradiol implantation in female virgin rats significantly decreases melatonin and AANAT activity [63]. Hernandez-Diaz et al. [64] findings lend support to the idea of an estrogen-mediated inhibition of melatonin synthesis in rat pinealocytes, possibly by causing a decrease in AANAT activity. With respect to progesterone, effects are brought about by research that shows a decrease in melatonin synthesis in female perfused pineal glands [65] and in postmenopausal women treated with progesterone during the dark period [66].

Based on currently available evidence and admitting the existence of results that are not so consensual, it is possible to suggest that reproductive hormones affect melatonin nocturnal peak, circulating levels, and duration of secretion. The physiologic consequences for such control are poorly studied and understood. The characteristics of the reciprocal relationship between melatonin and reproductive hormones are misunderstood and based on few publications that show dissenters to the view of melatonin interference on reproductive hormones and vice-versa (Fig. 2). Even though there is some inconsistency, there is a strong probability of a bidirectional communication. Indeed, it is viable that hormonal alterations associated with aging may adjust melatonin levels through regulation of AANAT activity. Besides, it is also plausible that direct or indirect actions of melatonin will support reproductive hormone fluctuations. Future studies on the 
current topic are therefore required in order to elucidate the impact during aging and in the control of climacteric symptoms.

\section{Regulatory Role of Melatonin in Gonadal Steroidogenesis: Involvement in Female and Male Reproduction}

\section{Male Gonads}

Leydig cells are located between the seminiferous tubules of the testis. These cells are responsible for synthesizing and secreting testosterone, which promotes the development of male reproductive tissues and plays a role on spermatogenesis and on the development of secondary sexual features [67]. Testosterone synthesis is induced by luteinizing hormone and cAMP signaling that promote the transfer of cholesterol to the inner mitochondrial membrane involving the steroidogenic acute regulatory protein (StAR). After that, cholesterol is converted into pregnenolone that is transformed into progesterone and subsequently metabolized to testosterone [68]. This similar steroidogenesis pathway occurs in the thecae cells and interstitial cells of the ovaries $[69,70]$. Melatonin may act similarly in the Leydig (testis) and thecae cells (ovary - see section below).

Pinealectomy induces alteration in steroidogenic gene expression, such as StAR and cytochrome P450 17A1 (Cyp17) in male gonads [71], and controls androgen production, which is important for male physiology and reproduction. In fact, melatonin regulates testosterone secretion [72-75], enhances the responsiveness of Sertoli cells to FSH during testicular development [76], and has a role in cellular growth, in proliferation, and in the secretory activity of testicular cells [77]. In addition, this hormone may protect the testis against the local generation of reactive oxygen species and inflammatory aggression. Also, melatonin appears to protect human spermatozoa from apoptosis $[78,79]$ since low melatonin levels are related with some cases of male infertility that include oligoasthenozoospermia or nonobstructive azoospermia $[78,80]$.

Testosterone production induced by LH stimulation is mediated by the cAMP signaling pathway in the Leydig cells. However, there are some endocrine and paracrine factors that act via cAMP-independent mechanisms and influence the androgen secretion regulation [81]. One of them is the testosterone secretion induced by $\mathrm{GnRH}$ stimulation that is mediated by PKC activation and increased cytosolic $\mathrm{Ca}^{2+}$ concentrations. Melatonin is able to block this process by suppressing the GnRH-dependent release of $\mathrm{Ca}^{2+}$ from intracellular stores in rat Leydig cells [82].

In addition, melatonin regulates the steroidogenesis through the StAR protein. In fact, Wu et al. [73] reported that melatonin inhibited StAR protein expression in MA10 mouse Leydig tumor cells. Other studies demonstrated that melatonin decreased StAR expression as well as other enzymes such as cytochrome P450 family 11 subfamily A member 1,3 $\beta$-hydroxysteroid dehydrogenase, and $17 \beta$-hydroxysteroid dehydrogenase type III in vitro and in vivo $[72,75]$. There are some pieces of evidence that melatonin may induce the expression of steroid $5 a$-reductase, which is important for the testicular conversion of testosterone into the active form $5 a$-dihydrotestosterone. Also, melatonin inhibits the expression of $3 a$-hydroxysteroid dehydrogenase, an enzyme that catalyzes the interconversion between $5 \alpha$-dihydrotestosterone and $3 \alpha$-androstanediol [75]. In addition, melatonin presents a crosstalk with the testicular corticotropin-releasing hormone system, which modulates testosterone production and increases the basal testosterone and cAMP concentration without affecting the maximum human chorionic gonadotropin (hCG)-stimulated testosterone synthesis [83-85].

The expression of MT1 and MT2 receptors has been reported in rat and bovine Sertoli cells [77], which are important for spermatogenesis efficiency and fertility [86]. In fact, Sertoli cells provide energy substrates such as lactate required to fuel germ cell metabolism. Melatonin decreases basal lactate production and upregulates the insulin-stimulated lactate generation, facilitating glucose uptake through the increase in GLUT1 protein levels and glucose consumption in rat Sertoli cells [87]. Melatonin also presents a modulatory role on the oxidant/antioxidant balance that maintains male fertility and spermatogenesis, since the testicular microenvironment is characterized by low oxygen tension and oxidative stress due to the abundance of highly unsaturated fatty acids and the presence of reactive oxygen species-generating systems including the mitochondria and a variety of enzymes that participate in spermatogenesis [88].

Melatonin also affects Sertoli cell growth and proliferation as it upregulates the expression of spermatogenesis-related genes including cyclin D1, cyclin E, plateletderived growth factor subunit A, desert hedgehog signaling molecule, occludin, and claudin in bovine Sertoli cells. Those genes may interfere in spermatogenesis. In addition, melatonin significantly increases inhibin B [89], considered a marker of Sertoli cell damage. Together, melatonin has multiple transduction pathways for modu- 
lating the Sertoli cell physiology and influencing spermatogenesis.

\section{Female Gonads}

The rat ovary presents MT1 and MT2 receptors in the secondary and tertiary follicles and luteal bodies, and their expression and capacity to bind melatonin vary along the estrous cycle phases [90]. Estrogens may influence melatonin receptor expression and function [90]. In addition, MT1 and MT2 receptor expression in the granulosa cells of the bovine gonad is regulated by melatonin itself [91].

Melatonin suppresses estradiol and progesterone synthesis on the preovulatory follicle in hamster ovary under hCG treatment [92], and the authors suggested that this effect was dependent on cAMP decrease. In fact, the hCG is a glycoprotein that presents an effect similar to $\mathrm{LH}$, which increases cAMP levels and the production of androgens [93], besides inducing the follicular changes to luteal cells that produce estradiol and progesterone [94]. This effect may have been blocked by the cAMP reduction caused by melatonin treatment.

Melatonin presents several effects on the ovaries. First, it influences the action of $\mathrm{LH}$ as its absence through pinealectomy determines a reduction in the ovulation rates [95] as well as intense histological changes, such as low number of luteal bodies, increase in the thecae cells and interstitial cell layers, and presence of microcysts in the periphery of the organ $[96,97]$. Those changes are similar to the ones observed in the ovaries of patients with polycystic ovarian syndrome [98]. In pinealectomized rats, melatonin administration may partially reverse those changes and restore the luteal bodies [95, 97, 99]. Also, other studies found that melatonin is important to reduce the thickness of the thecae layer and decrease the proliferation markers on those cells. The authors suggest that melatonin plays a role in the maintenance of a proper follicular morphology, being important for the ovulation process $[99,100]$.

Melatonin appears to be involved in the follicular dynamics, ovulation, degradation of luteal bodies, quality of oocyte, and steroidogenesis $[95,98,100]$. A recent study showed that melatonin acted on the sheep cumulus-oocyte complex that was important for quality of the oocyte [101]. Taking into consideration that sheep is a seasonal short-photoperiod reproductive species, the authors suggest that estrogen regulates local melatonin metabolism as well as interferes with its receptor expression $[90,101]$. In fact, Soares et al. [102] showed that estrogen levels may interfere with the activity of melatonin receptors (MT1 and MT2) in the rat granulosa cells. Therefore, estrogen may change the effect of the melatonin receptor on cAMP signaling [102]. Consequently, melatonin and estrogens seem to be coparticipants in the processes of follicular growth and angiogenesis as well as in the maintenance of the quality of the oocyte [101]. Those pieces of evidence may explain the reason for the follicular concentration of melatonin being 3 times higher than that found in the circulation [103]. In addition, Chuffa et al. [7] described that melatonin significantly reduced $\mathrm{LH}$ and estrogen blood levels as well as induced downregulation of estrogen receptor alpha and progesterone receptor beta expression in the ovaries during rat ovulation.

Melatonin plays a role in the ovary morphology and follicular dynamics [95] as well as in the integrity of the ovarian follicle. In fact, Wang et al. [104] demonstrated that melatonin may maintain follicular health through the inhibition of the apoptosis of granulosa cells that are important for the interaction between the granulosa cells and oocytes [105]. This action involved the proapoptotic protein $\mathrm{Bcl}$-2-interacting mediator of cell death-extra long (BimEL) since melatonin at $10^{-9} \mathrm{M}$ downregulated BimEL expression in in vitro porcine granulosa cells [104]. Moreover, BimEL controls the follicular atresia and the apoptosis of granulosa cells. In addition, high dose $(30 \mu \mathrm{g} / \mathrm{kg})$, but not low dose ( $3 \mu \mathrm{g} / \mathrm{kg})$, of oral melatonin determines increase in antral follicles in murine ovaries [106]. Therefore, it seems that high local melatonin concentration in the follicles is important for the protective action of this indolamine.

Circulating melatonin ablation after pinealectomy increases the expression of CYP11A1, CYP17A1, and CYP19A1, and melatonin replacement determines a decrease in CYP17A1 expression, mainly in the theca interna and interstitial cells [107]. Also, melatonin activation of the StAR and PI3K/AKT pathways in thecae cells influences androgen production. The MT2 receptor may be involved in the regulation of steroidogenesis by melatonin [108], and the PI3K/AKT pathway is important for steroidogenesis and apoptosis [109]. Therefore, melatonin may modulate the $\mathrm{LH}$ action in steroidogenesis and apoptosis through this pathway, at least, in ovarian thecae cells. A recent study showed that melatonin increased the expression of inhibin beta and follistatin in the ovaries of pinealectomized female rats, playing a role in the gonadotropin regulation, mainly on FSH, and in ovary steroidogenesis [110].

Other authors described that oral melatonin could improve the quality of oocytes in aged mice [111]. The age is a major factor for reducing the fertility and oocyte qual- 
ity in women undergoing in vitro fertilization-embryo transfer. In both situations, melatonin treatment showed positive effects $[112,113]$.

The high levels of melatonin in preovulatory follicles may have a role in progesterone synthesis by the human granulosa cells. Also, melatonin may interfere with the amount of the steroid receptor in the ovaries, mainly the progesterone receptor [99]. In summary, melatonin affects the ovaries in many ways: (a) increasing progesterone production in vitro and in vivo; (b) increasing estrogen production; (c) antagonizing estrogen action; (d) improving thecae cell quality, resulting in improved embryo and higher pregnancy rates; (e) improving cell proliferation via MAPK; (f) reducing free radicals; and (g) reducing the precocious follicular atresia.

\section{Melatonin Involvement in Hormonal Control in Females}

\section{Effects of Melatonin in Placental Hormones}

Throughout pregnancy, women undergo a myriad of hormonal and physiological adjustments which include the formation of a new, transient organ - the placenta. This autonomous organ displays unique features besides providing fetal nourishment and oxygenation. The placenta synthesizes many steroids and peptide hormones and acts as an autocrine, paracrine, and endocrine organ that contributes to the formation of a perfect environment for life development [114].

A healthy gestation depends, among other factors, on placental production of neuropeptides, growth factors, adipokines, pituitary-like hormones, and steroids. The present section focuses on melatonin involvement in pregnancy only. As previously described, the circulating melatonin pattern reflects the pineal synthesis rhythm, providing the organism far-reaching internal time cues $[11,13]$. However, a plethora of organs synthesize this indoleamine for local use $[115,116]$. In the female reproductive tract, extrapineal synthesis of melatonin occurs in the ovary [117], oocytes [118], granulosa cells [119], and placenta $[120,121]$.

Extrapineal sources of melatonin cause different melatonin concentrations, which diverge even among cellular compartments [115], hindering a consensus about what a melatonin "physiological concentration" is [122]. In the ovary, both syncytiotrophoblasts and villous cytotrophoblasts synthesize melatonin, as well as other 2 in vitro trophoblast models, JEG-3 and BeWo choriocarcinoma cells [121]. Moreover, placentas obtained from healthy wom- en in the first trimester and also near term presented functional AANAT and hydroxyindole-O-methyltransferase/ASMT enzymes [120, 121].

Besides its autocrine and paracrine effects, melatonin acts as a direct and indirect antioxidant $[119,123,124]$. Its molecular structure consists of a pyrrolic ring containing electrons that easily quench oxidative and nitrosative reactive species. These reactions generate other stable antioxidant molecules, such as cyclic 3-hydroxymelatonin, N1-acetyl-N2-formyl-5-methoxykynuramine, and N1acetyl-5-methoxykynuramine, whose free radical scavenging potentials are even higher than the one observed for melatonin $[125,126]$. Regarding its indirect antioxidant effects, melatonin increases the expression of antioxidant enzymes such as superoxide dismutase [59], glutathione peroxidase [123], and catalase [127]. Furthermore, this amphipathic molecule freely crosses all organism membranes, even reaching mitochondria where its role is crucial to quench free radicals in the electron transport chain, a highly oxidative process [128, 129].

Placenta-derived fetal nourishment, oxygenation, and excretion processes generate a significant amount of free radicals [130]. Oxidative stress is a physiological aspect needed for placental development, but yet there must be a balance between pro-oxidant molecules and antioxidant defenses [131].

Melatonin exerts its actions, including the antioxidant effects, by receptor-dependent and receptor-independent mechanisms. Placental villous trophoblasts express both melatonin MT1 and MT2 transmembrane receptors, although their precise role during pregnancy remains to be studied [121]. Other pregnancy-classical hormones might also interact with melatonin throughout this period.

In vitro studies reported an increase in progesterone synthesis by human luteal cells and rat granulosa cells when low concentrations of melatonin were added to the medium $[132,133]$, while estradiol synthesis remained unchanged. Nonetheless, when the media contained hCG and melatonin combined, estradiol concentrations increased [133]. Another experiment tested melatonin ability to increase either estrogen or progesterone in cell cultures of bovine and human granulosa cells. While low concentrations of melatonin did not influence either progesterone or estradiol outcome, incubation with higher doses stimulated progesterone, but not estradiol, secretion, and a dose/response concentration outcome was absent [134].

Towards the term, healthy pregnancies physiologically express higher levels of estrogen and progesterone [135]. 
In vivo experiments with pinealectomized rats showed even higher levels of plasma progesterone on gestational days 18 and 19 and also of estrogen on days 20 and 21 [136]. This study opposes the findings obtained in vitro, as previously described. Noteworthy, all plasmatic measurements were performed during the day, which could have misled some interpretations. Literature about the relation between melatonin and classical pregnancy-induced hormones is still scarce. However, there is plenty of evidence that melatonin participates in many processes throughout gestation, from embryo implantation to birth [137].

The relevance of melatonin during pregnancy, a remarkable characteristic of this hormone, is still not fully understood. Studies performed in humans and rats reported a significant increase in plasma melatonin concentrations towards the end of gestation, reaching the peak right before delivery and returning to basal rates in the following evening $[135,138-140]$. Human maternal melatonin levels increase approximately 4 times in comparison with their pregestational nocturnal concentrations [139]. Meanwhile, daytime variation in melatonin concentrations is still a matter of controversy. One group reported a decrease in early pregnancy followed by an increment on late gestational weeks [135]. Another study showed a daytime increase during the third semester [138], while the most recent one did not find any evidence of diurnal rise [139]. From our understanding, it seems unlikely to detect a rise in diurnal concentrations in this period; nonetheless, this question needs further investigation.

The last trimester increase in maternal melatonin positively relates to the number of children borne, both in humans and rats. Twins pregnancy presented a significant earlier surge in melatonin increase -24 weeks of gestation versus 28 weeks in singleton pregnancies. Additionally, circulating melatonin levels are higher in mothers of twins [139]. Rats also synthesize more melatonin towards the end of pregnancy, which is also relatable to the offspring quantity. Tamura et al. [140] tested the relation between the offspring quantity and melatonin increase. They reported a noticeable increase in this indolamine concentration in dams with 10 or more offspring, while single-offspring dams (surgically induced by fetectomy) showed secretion profiles comparable to control rats. Afterward, they collected, washed, and cultured placentas from $10+$ offspring pregnancies to obtain aliquots of the placental incubation medium supernatant. After 3 consecutive days of medium injection, the single-offspring pregnant dams prominently increased nocturnal melatonin levels to the same of the $10+$ offspring group. Performing the same procedure after charcoal addition to the medium resulted in unchanged basal melatonin levels. That points to a hypothesis in which some placental factors might trigger pineal melatonin increase towards the term [140].

The physiological increase in melatonin synthesis throughout pregnancy can be related to healthy outcomes, since maternal melatonin levels are reduced in the presence of gestational complications such as in intrauterine growth restriction, preeclampsia, and eclampsia $[139,141]$. Moreover, alterations in the circadian rhythm of melatonin reportedly increase the risk of preeclampsia in addition to altering this hormone secretion pattern [142].

Preeclampsia is an exclusive human dysfunction affecting 3-8\% of gestations worldwide. It can be defined as de novo pregnancy-induced hypertension in addition to proteinuria, among other complications that appear after 20 weeks of gestation, compromising the mother and the fetus [143]. Its pathogenesis is related to placental increased oxidative/nitrosative stress and apoptosis, which consequently augment the release of free radical species in the bloodstream, damaging the endothelium and leading to blood pressure elevation [144]. Considering melatonin direct and indirect antioxidant effects, its association in pregnancy was investigated.

The severity of preeclampsia relates negatively to circulating melatonin levels, meaning that women suffering from severe preeclampsia present less melatonin when compared to mild preeclampsia or healthy pregnant ones [139]. Based on this evidence, Lanoix and colleagues [145] investigated melatonin and its receptors in preeclamptic placentas. They showed that both hormone production and receptor expression are diminished when comparing this group to healthy controls. Preeclamptic women produce less melatonin and present diminished placental AANAT expression and a significant decrease in MT1 and MT2 placental receptors. Noteworthy, preeclamptic placentas display increased serotonin levels, pointing to a defective molecular cascade in melatonin production rather than a lack of the substrate for hormone conversion.

The presented data indicate a pivotal role of melatonin in the maintenance of healthy pregnancies. Low levels of melatonin during pregnancy are not only a complication to the mother, but also influences fetal programming in terms of fetus development, energy metabolism, cognition, and behavior until later in life [146-148]. 
Fig. 3. Melatonin's effects on menopause and/or postmenopause. Melatonin therapy is useful in preventing obesity and high cholesterol by reducing food intake in women undergoing menopause or postmenopause. Metabolic changes, dyslipidemia, and climacteric symptoms are also regulated by melatonin therapy.

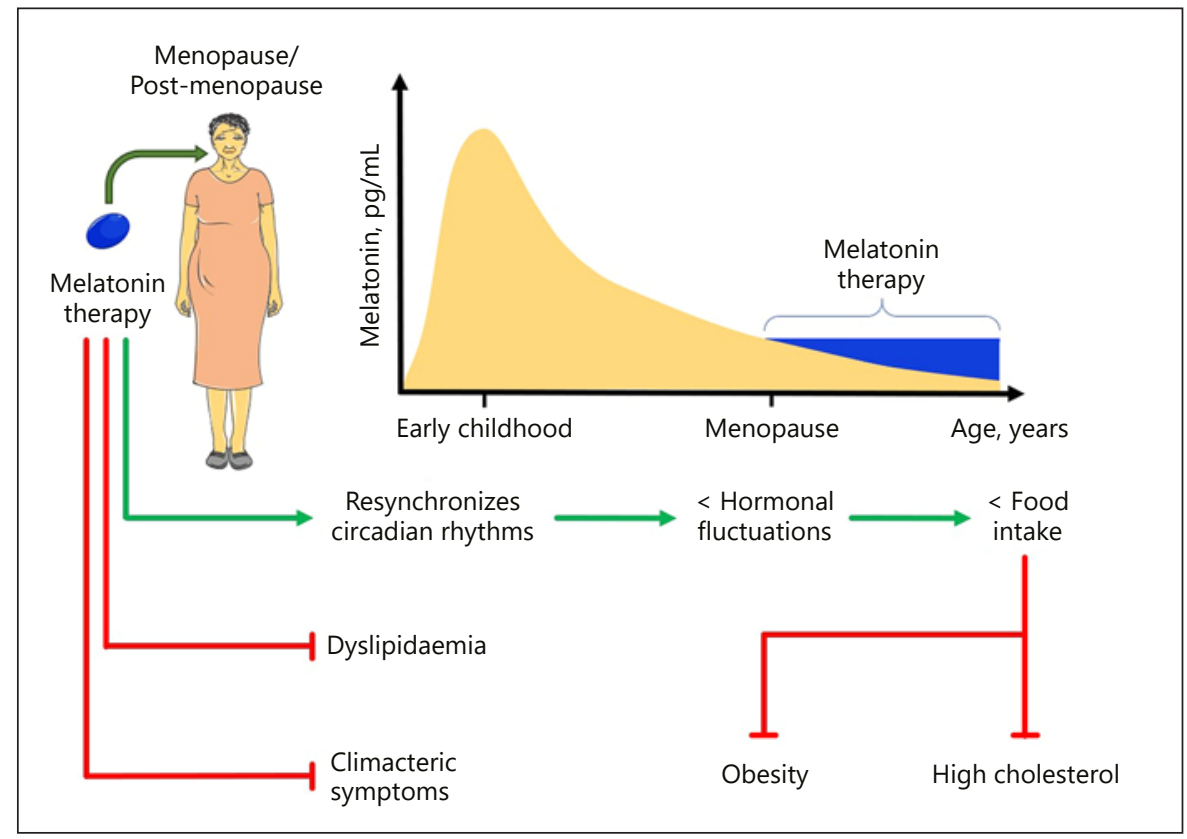

Melatonin assessment through the nocturnal excretion of its metabolite, aMT6s, is a practical and noninvasive method. As low concentration of melatonin could be a signal of preeclampsia, aMT6s dosage throughout pregnancy might be useful as a marker to be followed. This potent antioxidant could also be considered for clinical trials in women suffering from such conditions.

\section{Protective Actions of Melatonin in Menopausal and Postmenopausal Women}

Endocrine transition-menopause is characterized by disruption of estrogen-regulated systems such as thermoregulation, sleep, and circadian rhythms [149]. The potential reciprocal relationship between melatonin and reproductive hormones lends support to the use of pineal melatonin in the control of disruption of such systems, influencing sleep and mood. It is well documented that among menopausal and postmenopausal women, one of the major problems resides in deregulation of sleep/wake cycles, probably as a result of a reduction of not only estrogens but also melatonin levels [150]. The consensus view seems to be that melatonin administration resynchronizes circadian rhythms, affecting symptoms associated with hormonal fluctuations. In ovariectomized rats, melatonin treatment reduced food intake and prevented the increase of body weight and cholesterol, metabolic changes associated with menopause and postmenopause [151]. Further, another animal study reported that mela- tonin was more efficient than the combination of estrogens and melatonin in the regulation of dyslipidemia, suggesting a therapeutic alternative to control symptoms associated with transition-menopause [152]. Based on a clinical trial, melatonin administration to menopausal women significantly changed their reproductive hormone levels. Such regulation of FSH and LH levels was followed by a tendency to a reduction in climacteric symptoms [153]. Recent data contradicting previous studies suggested that melatonin administration to postmenopausal women does not alter FSH and estradiol plasma levels. Yet, melatonin therapy exerts real effects on the climacteric symptoms such as sleep, mood, and vasomotor dysfunctions [154]. However, other studies did not support a direct action of melatonin on climacteric symptoms [155].

Based on currently available evidence, it seems reasonable to suggest that melatonin is a therapeutic alternative to control the complexity of climacteric symptoms regardless of the deficiency of steroid hormones in menopausal and postmenopausal women (Fig. 3). Nonetheless, as other studies failed to observe a modulation of reproductive hormones by melatonin, the view of a different mechanism uncoupled to female reproductive hormones to justify the melatonin role in the improvement of climacteric symptoms may also be considered [154]. 


\section{Conclusion}

It is becoming clear that melatonin interacts with sex steroid hormones, in particular cases reciprocally, whereby melatonin action influences but is also being influenced by the sex steroids, thus a bidirectional relationship exists. This communication depends on the melatonin levels, age, hormonal status, tissue, and environmental conditions. Furthermore, the direct or indirect mechanistic pathways involved also bring to this interaction a high level of complexity.

Clinically, the relationship between melatonin and sex steroid hormones is of particular importance in female and male reproduction and in pregnancy in the case of treatment or prevention of preeclampsia as well as in the potential use of melatonin during the menopausal transition and beyond. It is clear, however, that the current knowledge is just the tip of the iceberg in a complex network of interactions in the crosstalk between melatonin and sex steroid hormones.

\section{Conflict of Interest Statement}

The authors have no conflicts of interest to declare.

\section{Funding Sources}

This work was financed by the Foundation for Science and Technology (FCT), through funds from the State Budget, and by the European Regional Development Fund (ERDF), under the Portugal 2020 Program, through the Regional Operational Program of the Centre (Centro 2020), through the Project with the reference UIDB/00709/2020, and supported by "Programa Operacional do Centro, Centro 2020" through the funding of the ICON project (Interdisciplinary Challenges On Neurodegeneration; CENTRO-01-0145-FEDER-000013)." André Furtado acknowledges funding from the grant UBI-Santander Totta (BID/ICI-FCS/ Santander Universidades-UBI/2019). This work was also supported by the São Paulo Research Foundation (FAPESP Grant No. 2014/50457-0).

\section{Author Contributions}

J.C.N., F.G.A., J.M.S., C.C., and T.Q. conceived the review, collected and analyzed the data, and wrote the paper. A.F., I.G., J.E.C., and C.S. revised the manuscript.

\section{References}

1 Cipolla-Neto J, Amaral FGD. Melatonin as a hormone: new physiological and clinical insights. Endocr Rev. 2018 Dec 1;39(6):9901028.

2 Pevet P. Melatonin. Dialogues Clin Neurosci. 2002 Mar;4(1):57-72.

3 Pevet P, Challet E. Melatonin: both master clock output and internal time-giver in the circadian clocks network. J Physiol Paris. 2011 Dec;105(4-6):170-82.

4 Goldman BD. Mammalian photoperiodic system: formal properties and neuroendocrine mechanisms of photoperiodic time measurement. J Biol Rhythms. 2001 Aug; 16(4):283-301.

5 Stevenson TJ, Prendergast BJ. Photoperiodic time measurement and seasonal immunological plasticity. Front Neuroendocrinol. 2015 Apr;37:76-88.

6 Reiter RJ, Sharma R. Central and peripheral actions of melatonin on reproduction in seasonal and continuous breeding mammals. Gen Comp Endocrinol. 2021 Jan 1;300: 113620.

7 Chuffa LG, Seiva FR, Fávaro WJ, Teixeira GR, Amorim JP, Mendes LO, et al. Melatonin reduces LH, 17 beta-estradiol and induces differential regulation of sex steroid receptors in reproductive tissues during rat ovulation. Reprod Biol Endocrinol. 2011 Aug 2;9:108.
8 Luboshitzky R, Lavie P. Melatonin and sex hormone interrelationships: a review. J Pediatr Endocrinol Metab. 1999 May-Jun;12(3): 355-62.

9 Simonneaux V, Ribelayga C. Generation of the melatonin endocrine message in mammals: a review of the complex regulation of melatonin synthesis by norepinephrine, peptides, and other pineal transmitters. Pharmacol Rev. 2003 Jun;55(2):325-95.

10 Skwarlo-Sonta K, Majewski P, Markowska M, Oblap R, Olszanska B. Bidirectional communication between the pineal gland and the immune system. Can J Physiol Pharmacol. 2003 Apr;81(4):342-9.

11 Reiter RJ. Pineal melatonin: cell biology of its synthesis and of its physiological interactions. Endocr Rev. 1991 May;12(2):151-80.

12 Mayo JC, Aguado A, Cernuda-Cernuda R, Álvarez-Artime A, Cepas V, Quirós-González I, et al. Melatonin uptake by cells: an answer to its relationship with glucose? Molecules. 2018 Aug 10;23(8).

13 Amaral FGD, Cipolla-Neto J. A brief review about melatonin, a pineal hormone. Arch Endocrinol Metab. 2018 Aug;62(4):472-9.

14 Liu J, Clough SJ, Hutchinson AJ, AdamahBiassi EB, Popovska-Gorevski M, Dubocovich ML. MT1 and MT2 melatonin receptors: a therapeutic perspective. Annu Rev Pharmacol Toxicol. 2016;56:361-83.
15 Pandi-Perumal SR, Trakht I, Srinivasan V, Spence DW, Maestroni GJ, Zisapel N, et al. Physiological effects of melatonin: role of melatonin receptors and signal transduction pathways. Prog Neurobiol. 2008 Jul;85(3): 335-53.

$16 \mathrm{Ng} \mathrm{KY}$, Leong MK, Liang H, Paxinos G. Melatonin receptors: distribution in mammalian brain and their respective putative functions. Brain Struct Funct. 2017 Sep;222(7):2921-39.

17 Slominski RM, Reiter RJ, Schlabritz-Loutsevitch N, Ostrom RS, Slominski AT. Melatonin membrane receptors in peripheral tissues: distribution and functions. Mol Cell Endocrinol. 2012 Apr 4;351(2):152-66.

18 Reiter RJ, Tan DX, Galano A. Melatonin: exceeding expectations. Physiology. 2014 Sep; 29(5):325-33.

19 Penny R. Melatonin excretion in normal males and females: increase during puberty. Metab Clin Exp. 1982 Aug;31(8):816-23.

20 Mongrain V, Lavoie S, Selmaoui B, Paquet J, Dumont $\mathrm{M}$. Phase relationships between sleep-wake cycle and underlying circadian rhythms in morningness-eveningness. J Biol Rhythms. 2004 Jun;19(3):248-57.

21 Cain SW, Dennison CF, Zeitzer JM, Guzik AM, Khalsa SB, Santhi N, et al. Sex differences in phase angle of entrainment and melatonin amplitude in humans. J Biol Rhythms. 2010 Aug;25(4):288-96. 
22 Gunn PJ, Middleton B, Davies SK, Revell VL, Skene DJ. Sex differences in the circadian profiles of melatonin and cortisol in plasma and urine matrices under constant routine conditions. Chronobiol Int. 2016;33(1):39-50.

23 Thrift AP, Xiao L, Patel SR, Tworoger SS, McTiernan A, Duggan C. Effects of physical activity on melatonin levels in previously sedentary men and women. Cancer Epidemiol Biomarkers Prev. 2014 Aug;23(8):1696-9.

24 Burgess HJ, Fogg LF. Individual differences in the amount and timing of salivary melatonin secretion. PLoS One. 2008 Aug 26;3(8):e3055.

25 Boivin DB, Shechter A, Boudreau P, Begum EA, Ng Ying-Kin NM. Diurnal and circadian variation of sleep and alertness in men vs. naturally cycling women. Proc Natl Acad Sci U S A. 2016 Sep 27;113(39):10980-5.

26 Santhi N, Lazar AS, McCabe PJ, Lo JC, Groeger JA, Dijk DJ. Sex differences in the circadian regulation of sleep and waking cognition in humans. Proc Natl Acad Sci U S A. 2016 May 10;113(19):E2730-9.

27 Kostoglou-Athanassiou I, Athanassiou P, Treacher DF, Wheeler MJ, Forsling ML. Neurohypophysial hormone and melatonin secretion over the natural and suppressed menstrual cycle in premenopausal women. Clin Endocrinol. 1998 Aug;49(2):209-16.

28 Malpaux B, Migaud M, Tricoire H, Chemineau P. Biology of mammalian photoperiodism and the critical role of the pineal gland and melatonin. J Biol Rhythms. 2001 Aug;16(4) 336-47.

29 Wright J, Aldhous M, Franey C, English J, Arendt J. The effects of exogenous melatonin on endocrine function in man. Clin Endocrinol. 1986 Apr;24(4):375-82.

30 Waldhauser F, Lieberman HR, Lynch HJ, Waldhauser M, Herkner K, Frisch H, et al. A pharmacological dose of melatonin increases PRL levels in males without altering those of $\mathrm{GH}, \mathrm{LH}, \mathrm{FSH}, \mathrm{TSH}$, testosterone or cortisol. Neuroendocrinology. 1987 Aug;46(2):125-30.

31 Luboshitzky R, Levi M, Shen-Orr Z, Blumenfeld Z, Herer P, Lavie P. Long-term melatonin administration does not alter pituitary-gonadal hormone secretion in normal men. Hum Reprod. 2000 Jan;15(1):60-5.

32 Rajaratnam SM, Dijk DJ, Middleton B, Stone $\mathrm{BM}$, Arendt J. Melatonin phase-shifts human circadian rhythms with no evidence of changes in the duration of endogenous melatonin secretion or the 24-hour production of reproductive hormones. J Clin Endocrinol Metab. 2003 Sep;88(9):4303-9.

33 Lang U, Aubert ML, Conne BS, Bradtke JC, Sizonenko PC. Influence of exogenous melatonin on melatonin secretion and the neuroendocrine reproductive axis of intact male rats during sexual maturation. Endocrinology. 1983 May;112(5):1578-84.

34 Aleem FA, Weitzman ED, Weinberg U. Suppression of basal luteinizing hormone concentrations by melatonin in postmenopausal women. Fertil Steril. 1984 Dec;42(6):923-5.
35 Cagnacci A, Elliott JA, Yen SS. Amplification of pulsatile LH secretion by exogenous melatonin in women. J Clin Endocrinol Metab. 1991 Jul;73(1):210-2.

36 Cagnacci A, Paoletti AM, Soldani R, Orrù M, Maschio E, Melis GB. Melatonin enhances the luteinizing hormone and follicle-stimulating hormone responses to gonadotropin-releasing hormone in the follicular, but not in the luteal, menstrual phase. J Clin Endocrinol Metab. 1995 Apr;80(4):1095-9.

37 Voordouw BC, Euser R, Verdonk RE, Alberda BT, de Jong FH, Drogendijk AC, et al. Melatonin and melatonin-progestin combinations alter pituitary-ovarian function in women and can inhibit ovulation. J Clin Endocrinol Metab. 1992 Jan;74(1):108-17.

38 Bellipanni G, Bianchi P, Pierpaoli W, Bulian D, Ilyia E. Effects of melatonin in perimenopausal and menopausal women: a randomized and placebo controlled study. Esp. Gerontol. 2001 Feb;36(2):297-310.

39 Diaz E, Pazo D, Esquifino AI, Diaz B. Effects of ageing and exogenous melatonin on pituitary responsiveness to $\mathrm{GnRH}$ in rats. J Reprod Fertil. 2000 May;119(1):151-6.

40 Diaz Lopez B, Diaz Rodriguez E, Urquijo C, Fernandez Alvarez C. Melatonin influences on the neuroendocrine-reproductive axis. Ann N Y Acad Sci. 2005 Dec;1057:337-64.

41 Chuffa LG, Seiva FR, Fávaro WJ, Amorim JP, Teixeira GR, Mendes LO, et al. Melatonin and ethanol intake exert opposite effects on circulating estradiol and progesterone and differentially regulate sex steroid receptors in the ovaries, oviducts, and uteri of adult rats. Reprod Toxicol. 2013 Aug;39:40-9.

42 Rendon NM, Rudolph LM, Sengelaub DR, Demas GE. The agonistic adrenal: melatonin elicits female aggression via regulation of adrenal androgens. Proc Biol Sci. 2015 Nov 22; 282(1819):282.

43 Bittman EL, Kaynard AH, Olster DH, Robinson JE, Yellon SM, Karsch FJ. Pineal melatonin mediates photoperiodic control of pulsatile luteinizing hormone secretion in the ewe. Neuroendocrinology. 1985 May;40(5):40918.

44 Malpaux B, Thiéry JC, Chemineau P. Melatonin and the seasonal control of reproduction. Reprod Nutr Dev. 1999 May-Jun;39(3):35566.

45 Revel FG, Ansel L, Klosen P, Saboureau M, Pévet P, Mikkelsen JD, et al. Kisspeptin: a key link to seasonal breeding. Rev Endocr Metab Disord. 2007 Mar;8(1):57-65.

46 Roy D, Belsham DD. Melatonin receptor activation regulates $\mathrm{GnRH}$ gene expression and secretion in GT1-7 GnRH neurons. Signal transduction mechanisms. J Biol Chem. 2002 Jan 4;277(1):251-8.

47 Revel FG, Saboureau M, Masson-Pévet M, Pévet P, Mikkelsen JD, Simonneaux V. Kisspeptin mediates the photoperiodic control of reproduction in hamsters. Curr Biol. 2006 Sep 5;16(17):1730-5.
48 Cos S, Gonzalez A, Martinez-Campa C, Mediavilla MD, Alonso-Gonzalez C, SanchezBarcelo EJ. Melatonin as a selective estrogen enzyme modulator. Curr Cancer Drug Targets. 2008 Dec;8(8):691-702.

49 Gonzalez A, Cos S, Martinez-Campa C, Alonso-Gonzalez C, Sanchez-Mateos S, Mediavilla $\mathrm{MD}$, et al. Selective estrogen enzyme modulator actions of melatonin in human breast cancer cells. J Pineal Res. 2008 Aug;45(1):86-92.

50 Sirotkin AV. Direct influence of melatonin on steroid, nonapeptide hormones, and cyclic nucleotide secretion by granulosa cells isolated from porcine ovaries. J Pineal Res. 1994 Oct:17(3):112-7.

51 Cardinali DP, Nagle CA, Rosner JM. Effects of estradiol on melatonin and protein synthesis in the rat pineal organ. Horm Res. 1974; 5(5):304-10.

52 Vacas MI, Lowenstein PR, Cardinali DP. Characterization of a cytosol progesterone receptor in bovine pineal gland. Neuroendocrinology. 1979;29(2):84-9.

53 Luboshitzky R, Dharan M, Goldman D, Herer P, Hiss Y, Lavie P. Seasonal variation of gonadotropins and gonadal steroids receptors in the human pineal gland. Brain Res Bull. 1997; 44(6):665-70.

54 Alonso-Solis R, Abreu P, Lopez-Coviella I, Hernandez G, Fajardo N, Hernandez-Diaz F, et al. Gonadal steroid modulation of neuroendocrine transduction: a transynaptic view. Cell Mol Neurobiol. 1996 Jun;16(3):357-82.

55 Luboshitzky R, Lavi S, Thuma I, Lavie P. Testosterone treatment alters melatonin concentrations in male patients with gonadotropinreleasing hormone deficiency. J Clin Endocrinol Metab. 1996 Feb;81(2):770-4.

56 Martin MS, Bogdan A, Touitou Y. Day-night differences in the effects of gonadal hormones on melatonin release from perifused rat pineals. Evidence of a circadian control. Steroids. 1996 Jan;61(1):27-32.

57 Fernandez B, Malde JL, Montero A, Acuña D. Relationship between adenohypophyseal and steroid hormones and variations in serum and urinary melatonin levels during the ovarian cycle, perimenopause and menopause in healthy women. J Steroid Biochem. $1990 \mathrm{Feb}$; 35(2):257-62.

58 Toffol E, Kalleinen N, Haukka J, Vakkuri O, Partonen T, Polo-Kantola P. Melatonin in perimenopausal and postmenopausal women: associations with mood, sleep, climacteric symptoms, and quality of life. Menopause. 2014 May;21(5):493-500.

59 Okatani Y, Morioka N, Wakatsuki A. Changes in nocturnal melatonin secretion in perimenopausal women: correlation with endogenous estrogen concentrations. J Pineal Res. 2000 Mar;28(2):111-8

60 Okatani Y, Sagara Y. Amplification of nocturnal melatonin secretion in women with functional secondary amenorrhoea: relation to endogenous oestrogen concentration. Clin Endocrinol. 1994 Dec;41(6):763-70. 
61 Delfs TM, Baars S, Fock C, Schumacher M, Olcese J, Zimmermann RC. Sex steroids do not alter melatonin secretion in the human. Hum Reprod. 1994 Jan;9(1):49-54.

62 Cardinali DP, Vacas MI, Keller Sarmiento MI, Etchegoyen GS, Pereyra EN, Chuluyan HE. Neuroendocrine integrative mechanisms in mammalian pineal gland: effects of steroid and adenohypophysial hormones on melatonin synthesis in vitro. J Steroid Biochem. 1987;27(1-3):565-71.

63 Okatani Y, Morioka N, Hayashi K. Changes in nocturnal pineal melatonin synthesis during the perimenopausal period: relation to estrogen levels in female rats. J Pineal Res. 1999 Sep;27(2):65-72.

64 Hernandez-Diaz FJ, Sanchez JJ, Abreu P, Lopez-Coviella I, Tabares L, Prieto L, et al. Estrogen modulates alpha(1)/beta-adrenoceptor- induced signaling and melatonin production in female rat pinealocytes. Neuroendocrinology. 2001 Feb;73(2):11122.

65 San Martin M, Touitou Y. Progesterone inhibits, on a circadian basis, the release of melatonin by rat pineal perifusion. Steroids. 2000 Apr;65(4):206-9.

66 Caufriez A, Leproult R, L'Hermite-Balériaux M, Kerkhofs M, Copinschi G. Progesterone prevents sleep disturbances and modulates $\mathrm{GH}$, TSH, and melatonin secretion in postmenopausal women. J Clin Endocrinol Metab. 2011 Apr;96(4):E614-23.

67 Haider SG. Cell biology of Leydig cells in the testis. Int Rev Cytol. 2004;233:181-241.

68 Payne AH, Hales DB. Overview of steroidogenic enzymes in the pathway from cholesterol to active steroid hormones. Endocr Rev. 2004 Dec;25(6):947-70.

69 Mahamed RR, Maganhin CC, Sasso GRS, de Jesus Simões M, Baracat MCP, Baracat EC, et al. Metformin improves ovarian follicle dynamics by reducing theca cell proliferation and CYP-17 expression in an androgenized rat model. J Ovarian Res. 2018 Mar 1;11(1): 18.

70 Astapova O, Minor BMN, Hammes SR. Physiological and pathological androgen actions in the ovary. Endocrinology. 2019 May 1; 160(5):1166-74.

71 Baburski AZ, Sokanovic SJ, Janjic MM, Stojkov-Mimic NJ, Bjelic MM, Andric SA, et al. Melatonin replacement restores the circadian behavior in adult rat Leydig cells after pinealectomy. Mol Cell Endocrinol. 2015 Sep 15; 413:26-35.

72 Maitra SK, Ray AK. Role of light in the mediation of acute effects of a single afternoon melatonin injection on steroidogenic activity of testis in the rat. J Biosci. 2000 Sep;25(3): 253-6.

73 Wu CS, Leu SF, Yang HY, Huang BM. Melatonin inhibits the expression of steroidogenic acute regulatory protein and steroidogenesis in MA-10 cells. J Androl. 2001 Mar-Apr; 22(2):245-54.
74 Pratis K, O’Donnell L, Ooi GT, Stanton PG, McLachlan RI, Robertson DM. Differential regulation of rat testicular 5alpha-reductase type 1 and 2 isoforms by testosterone and FSH. J Endocrinol. 2003 Mar;176(3):393-403.

75 Frungieri MB, Mayerhofer A, Zitta K, Pignataro OP, Calandra RS, Gonzalez-Calvar SI. Direct effect of melatonin on Syrian hamster testes: melatonin subtype 1a receptors, inhibition of androgen production, and interaction with the local corticotropin-releasing hormone system. Endocrinology. 2005 Mar; 146(3):1541-52.

76 Heindel JJ, Jackson FL, Berkowitz AS. Role of the pineal in the alteration of hamster Sertoli cell responsiveness to FSH during testicular regression. J Androl. 1984 May-Jun;5(3): 211-5.

77 Frungieri MB, Calandra RS, Rossi SP. Local actions of melatonin in somatic cells of the testis. Int J Mol Sci. 2017 May 31;18(6):1170.

78 Yie SM, Daya S, Brown GM, Deys L, YoungLai EV. Melatonin and aromatase stimulating activity of human seminal plasma. Andrologia. 1991 May-Jun;23(3):227-31.

79 Espino J, Ortiz Á, Bejarano I, Lozano GM, Monllor F, García JF, et al. Melatonin protects human spermatozoa from apoptosis via melatonin receptor- and extracellular signal-regulated kinase-mediated pathways. Fertil Steril. 2011 Jun;95(7):2290-6.

80 Awad H, Halawa F, Mostafa T, Atta H. Melatonin hormone profile in infertile males. Int $\mathrm{J}$ Androl. 2006 Jun;29(3):409-13.

81 Saez JM. Leydig cells: endocrine, paracrine, and autocrine regulation. Endocr Rev. 1994 Oct;15(5):574-626.

82 Valenti S, Thellung S, Florio T, Giusti M, Schettini G, Giordano G. A novel mechanism for the melatonin inhibition of testosterone secretion by rat Leydig cells: reduction of GnRH-induced increase in cytosolic $\mathrm{Ca} 2+. \mathrm{J}$ Mol Endocrinol. 1999 Dec;23(3):299-306.

83 Huang BM, Stocco DM, Hutson JC, Norman RL. Corticotropin-releasing hormone stimulates steroidogenesis in mouse Leydig cells. Biol Reprod. 1995 Sep;53(3):620-6.

84 Cui P, Yu M, Luo Z, Dai M, Han J, Xiu R, et al. Intracellular signaling pathways involved in cell growth inhibition of human umbilical vein endothelial cells by melatonin. J Pineal Res. 2008 Jan;44(1):107-14.

85 Rossi SP, Matzkin ME, Terradas C, Ponzio R, Puigdomenech E, Levalle $\mathrm{O}$, et al. New insights into melatonin/CRH signaling in hamster Leydig cells. Gen Comp Endocrinol. 2012 Aug 1;178(1):153-63.

86 McLachlan RI, Wreford NG, O’Donnell L, de Kretser DM, Robertson DM. The endocrine regulation of spermatogenesis: independent roles for testosterone and FSH. J Endocrinol. 1996 Jan;148(1):1-9.

87 Rocha CS, Martins AD, Rato L, Silva BM, Oliveira PF, Alves MG. Melatonin alters the glycolytic profile of Sertoli cells: implications for male fertility. Mol Hum Reprod. 2014 Nov;20(11):1067-76.
88 Agbaje IM, Rogers DA, McVicar CM, McClure N, Atkinson AB, Mallidis C, et al. Insulin dependant diabetes mellitus: implications for male reproductive function. Hum Reprod. 2007 Jul;22(7):1871-7.

89 Yang WC, Tang KQ, Fu CZ, Riaz H, Zhang Q, Zan LS. Melatonin regulates the development and function of bovine Sertoli cells via its receptors MT1 and MT2. Anim Reprod Sci. 2014 Jun 10;147(1-2):10-6.

90 Soares JM Jr, Masana MI, Erşahin C, Dubocovich ML. Functional melatonin receptors in rat ovaries at various stages of the estrous cycle. J Pharmacol Exp Ther. 2003 Aug;306(2):694-702.

91 Wang SJ, Liu WJ, Wu CJ, Ma FH, Ahmad S, Liu BR, et al. Melatonin suppresses apoptosis and stimulates progesterone production by bovine granulosa cells via its receptors (MT1 and MT2). Theriogenology. 2012 Oct 15; 78(7):1517-26.

92 Tamura H, Nakamura Y, Takiguchi S, Kashida S, Yamagata Y, Sugino N, et al. Melatonin directly suppresses steroid production by preovulatory follicles in the cyclic hamster. J Pineal Res. 1998 Oct;25(3):135-41.

93 Palaniappan M, Menon KM. Human chorionic gonadotropin stimulates theca-interstitial cell proliferation and cell cycle regulatory proteins by a cAMP-dependent activation of AKT/mTORC1 signaling pathway. Mol Endocrinol. 2010 Sep;24(9):1782-93.

94 Bowdridge EC, Vernon MW, Flores JA, Clemmer MJ. In vitro progesterone production by luteinized human mural granulosa cells is modulated by activation of AMPK and cause of infertility. Reprod Biol Endocrinol. 2017 Sep 22;15(1):76.

95 Dair EL, Simoes RS, Simões MJ, Romeu LR, Oliveira-Filho RM, Haidar MA, et al. Effects of melatonin on the endometrial morphology and embryo implantation in rats. Fertil Steril. 2008 May;89(5 Suppl):1299-305.

96 Soares JM Jr, Simões MJ, Oshima CT, Mora OA, De Lima GR, Baracat EC. Pinealectomy changes rat ovarian interstitial cell morphology and decreases progesterone receptor expression. Gynecol Endocrinol. 2003 Apr; 17(2):115-23.

97 Lombardi LA, de Mattos LS, Simões RS, Florencio-Silva R, da Silva Sasso GR, Carbonel $\mathrm{AAF}$, et al. Melatonin may prevent or reverse polycystic ovary syndrome in rats. Rev Assoc Med Bras. 2019 Aug 5;65(7):1008-14.

98 Otsuka F. Modulation of bone morphogenetic protein activity by melatonin in ovarian steroidogenesis. Reprod Med Biol. 2018 Jul; 17(3):228-33.

99 Romeu LR, da Motta EL, Maganhin CC, Oshima CT, Fonseca MC, Barrueco KF, et al. Effects of melatonin on histomorphology and on the expression of steroid receptors, VEGF, and PCNA in ovaries of pinealectomized female rats. Fertil Steril. 2011 Mar 15;95(4): 1379-84. 
100 Maganhin CC, Fuchs LF, Simões RS, Oliveira-Filho RM, de Jesus Simões M, Baracat EC, et al. Effects of melatonin on ovarian follicles. Eur J Obstet Gynecol Reprod Biol. 2013 Feb;166(2):178-84.

101 Xiao L, Hu J, Song L, Zhang Y, Dong W, Jiang $Y$, et al. Profile of melatonin and its receptors and synthesizing enzymes in cumulus-oocyte complexes of the developing sheep antral follicle-a potential estradiolmediated mechanism. Reprod Biol Endocrinol. 2019 Jan 3;17(1):1.

102 Masana MI, Soares JM Jr, Dubocovich ML 17Beta-estradiol modulates hMT1 melatonin receptor function. Neuroendocrinology. 2005;81(2):87-95.

103 Brzezinski A, Seibel MM, Lynch HJ, Deng $\mathrm{MH}$, Wurtman RJ. Melatonin in human preovulatory follicular fluid. J Clin Endocrinol Metab. 1987 Apr;64(4):865-7.

104 Wang H, Pu Y, Luo L, Li Y, Zhang Y, Cao Z. Membrane receptor-independent inhibitory effect of melatonin on androgen production in porcine theca cells. Theriogenology. 2018 Sep 15;118:63-71.

105 Uyar A, Torrealday S, Seli E. Cumulus and granulosa cell markers of oocyte and embryo quality. Fertil Steril. 2013 Mar 15; 99(4):979-97.

106 Zhao X, Wang D, Wu Z, Pan B, Yang H, Zeng $\mathrm{C}$, et al. Female reproductive performance in the mouse: effect of oral melatonin. Molecules. 2018 Jul 25;23(8):1845.

107 Maganhin CC, Simões RS, Fuchs LF, Sasso GR, Simões MJ, Baracat EC, et al. Melatonin influences on steroidogenic gene expression in the ovary of pinealectomized rats. Fertil Steril. 2014 Jul;102(1):291-8.

108 Wang X, Meng K, He Y, Wang H, Zhang Y, Quan F. Melatonin stimulates STAR expression and progesterone production via activation of the PI3K/AKT pathway in bovine theca cells. Int J Biol Sci. 2019;15(2): 404-15.

109 Wang X, Zou P, He Y, Meng K, Quan F, Zhang Y. Effect of luteinizing hormone on goat theca cell apoptosis and steroidogenesis through activation of the PI3K/AKT pathway. Anim Reprod Sci. 2018 Mar; 190: $108-18$.

110 Maganhin CC, Baracat MCP, Carvalho KC, Seganfredo IB, Luquetti CM, Dos Santos Simões R, et al. Evidence that melatonin increases inhibin beta-A and follistatin gene expression in ovaries of pinealectomized rats. Reprod Sci. 2020 Jul;27(7):1455-64.

111 Tamura H, Kawamoto M, Sato S, Tamura I, Maekawa R, Taketani T, et al. Long-term melatonin treatment delays ovarian aging. I Pineal Res. 2017 Mar;62(2).

112 Nishihara T, Hashimoto S, Ito K, Nakaoka Y, Matsumoto K, Hosoi Y, et al. Oral melatonin supplementation improves oocyte and embryo quality in women undergoing in vitro fertilization-embryo transfer. Gynecol Endocrinol. 2014 May;30(5):359-62.
113 Song C, Peng W, Yin S, Zhao J, Fu B, Zhang $\mathrm{J}$, et al. Melatonin improves age-induced fertility decline and attenuates ovarian mitochondrial oxidative stress in mice. Sci Rep. 2016 Oct 12;6:35165.

114 Cross JC. Placental function in development and disease. Reprod Fertil Dev. 2006; 18(1-2):71-6.

115 Venegas C, García JA, Escames G, Ortiz F, López A, Doerrier C, et al. Extrapineal melatonin: analysis of its subcellular distribution and daily fluctuations. J Pineal Res. 2012 Mar;52(2):217-27.

116 Acuna-Castroviejo D, Escames G, Venegas C, Diaz-Casado ME, Lima-Cabello E, Lopez LC, et al. Extrapineal melatonin: sources, regulation, and potential functions. Cell Mol Life Sci. 2014 Aug;71(16):2997-3025.

117 Itoh MT, Ishizuka B, Kudo Y, Fusama S, Amemiya A, Sumi Y. Detection of melatonin and serotonin $\mathrm{N}$-acetyltransferase and hydroxyindole-O-methyltransferase activities in rat ovary. Mol Cell Endocrinol. 1997 Dec 31;136(1):7-13.

118 Sakaguchi K, Itoh MT, Takahashi N, Tarumi W, Ishizuka B. The rat oocyte synthesises melatonin. Reprod Fertil Dev. 2013; 25(4):674-82.

119 El-Raey M, Geshi M, Somfai T, Kaneda M, Hirako M, Abdel-Ghaffar AE, et al. Evidence of melatonin synthesis in the cumulus oocyte complexes and its role in enhancing oocyte maturation in vitro in cattle. Mol Reprod Dev. 2011 Apr;78(4):250-62.

120 Iwasaki S, Nakazawa K, Sakai J, Kometani K, Iwashita M, Yoshimura Y, et al. Melatonin as a local regulator of human placental function. J Pineal Res. 2005 Oct;39(3):261-5.

121 Lanoix D, Beghdadi H, Lafond J, Vaillancourt C. Human placental trophoblasts synthesize melatonin and express its receptors. J Pineal Res. 2008 Aug;45(1):50-60.

122 Reiter RJ, Tan DX. What constitutes a physiological concentration of melatonin? J Pineal Res. 2003 Jan;34(1):79-80.

123 Okatani Y, Wakatsuki A, Shinohara K, Taniguchi K, Fukaya T. Melatonin protects against oxidative mitochondrial damage induced in rat placenta by ischemia and reperfusion. J Pineal Res. 2001 Sep;31(2):173-8.

124 de Matos Cavalcante AG, de Bruin PF, de Bruin VM, Nunes DM, Pereira ED, Cavalcante $\mathrm{MM}$, et al. Melatonin reduces lung oxidative stress in patients with chronic obstructive pulmonary disease: a randomized, double-blind, placebo-controlled study. J Pineal Res. 2012 Oct;53(3):238-44.

125 Tan DX, Manchester LC, Burkhardt S, Sainz RM, Mayo JC, Kohen R, et al. N1-acetyl-N2formyl-5-methoxykynuramine, a biogenic amine and melatonin metabolite, functions as a potent antioxidant. FASEB J. 2001 Oct; 15(12):2294-6
126 Ressmeyer AR, Mayo JC, Zelosko V, Sáinz RM, Tan DX, Poeggeler B, et al. Antioxidant properties of the melatonin metabolite N1acetyl-5-methoxykynuramine (AMK): scavenging of free radicals and prevention of protein destruction. Redox Rep. 2003; $8(4): 205-13$.

127 Mayo JC, Tan DX, Sainz RM, Lopez-Burillo S, Reiter RJ. Oxidative damage to catalase induced by peroxyl radicals: functional protection by melatonin and other antioxidants. Free Radic Res. 2003 May;37(5):54353.

128 Acuna-Castroviejo D, Escames G, Rodriguez MI, Lopez LC. Melatonin role in the mitochondrial function. Front Biosci. 2007 Jan 1;12:947-63.

129 Reiter RJ, Tan DX, Rosales-Corral S, Galano A, Zhou XJ, Xu B. Mitochondria: central organelles for melatonin's antioxidant and anti-aging actions. Molecules. 2018 Feb 24; 23(2):509.

130 Agarwal A, Aponte-Mellado A, Premkumar BJ, Shaman A, Gupta S. The effects of oxidative stress on female reproduction: a review. Reprod Biol Endocrinol. 2012 Jun 29;10:49.

131 Burton GJ, Jauniaux E. Placental oxidative stress: from miscarriage to preeclampsia. J Soc Gynecol Investig. 2004 Sep;11(6):34252.

132 MacPhee AA, Cole FE, Rice BF. The effect of melatonin on steroidogenesis by the human ovary in vitro. J Clin Endocrinol Metab. 1975 Apr;40(4):688-96.

133 Fiske VM, Parker KL, Ulmer RA, Ow CH, Aziz N. Effect of melatonin alone or in combination with human chorionic gonadotropin or ovine luteinizing hormone on the in vitro secretion of estrogens or progesterone by granulosa cells of rats. Endocrinology. 1984 Feb;114(2):407-10.

134 Webley GE, Luck MR. Melatonin directly stimulates the secretion of progesterone by human and bovine granulosa cells in vitro. J Reprod Fertil. 1986 Nov;78(2):711-7.

135 Pang SF, Tang PL, Tang GW, Yam AW, Ng KW. Plasma levels of immunoreactive melatonin, estradiol, progesterone, follicle stimulating hormone, and beta-human chorionic gonadotropin during pregnancy and shortly after parturition in humans. J Pineal Res. 1987;4(1):21-31.

136 Nir I, Hirschmann N. The effect of pinealectomy on serum progesterone and oestradiol levels during the last stage of pregnancy in rats. Experientia. $1980 \mathrm{Feb}$ 15;36(2):259-60.

137 Carlomagno G, Minini M, Tilotta M, Unfer V. From implantation to birth: insight into molecular melatonin functions. Int $\mathrm{J} \mathrm{Mol}$ Sci. 2018 Sep 17;19(9):2802.

138 Kivela A. Serum melatonin during human pregnancy. Acta Endocrinol. 1991 Mar; 124(3):233-7. 
139 Nakamura Y, Tamura H, Kashida S, Takayama H, Yamagata Y, Karube A, et al. Changes of serum melatonin level and its relationship to feto-placental unit during pregnancy. J Pineal Res. 2001 Jan;30(1):29-33.

140 Tamura H, Takayama H, Nakamura Y, Reiter RJ, Sugino N. Fetal/placental regulation of maternal melatonin in rats. J Pineal Res. 2008 Apr;44(3):335-40.

141 Reiter RJ, Tan DX, Korkmaz A, RosalesCorral SA. Melatonin and stable circadian rhythms optimize maternal, placental and fetal physiology. Hum Reprod Update. 2014 Mar-Apr;20(2):293-307.

142 Tranquilli AL, Turi A, Giannubilo SR, Garbati E. Circadian melatonin concentration rhythm is lost in pregnant women with altered blood pressure rhythm. Gynecol Endocrinol. 2004 Mar;18(3):124-9.

143 Anderson UD, Olsson MG, Kristensen KH, Åkerström B, Hansson SR. Review: biochemical markers to predict preeclampsia. Placenta. 2012 Feb;33 Suppl:S42-7.

144 Wiktor H, Kankofer M, Schmerold I, Dadak A, Lopucki M, Niedermüller H. Oxidative DNA damage in placentas from normal and pre-eclamptic pregnancies. Virchows Arch. 2004 Jul;445(1):74-8.
145 Lanoix D, Guérin P, Vaillancourt C. Placental melatonin production and melatonin receptor expression are altered in preeclampsia: new insights into the role of this hormone in pregnancy. J Pineal Res. 2012 Nov; 53(4):417-25.

146 Bellavia SL, Carpentieri AR, Vaque AM, Macchione AF, Vermouth NT. Pup circadian rhythm entrainment: effect of maternal ganglionectomy or pinealectomy. Physiol Behav. 2006 Oct 30;89(3):342-9.

147 Ferreira DS, Amaral FG, Mesquita CC, Barbosa AP, Lellis-Santos C, Turati AO, et al. Maternal melatonin programs the daily pattern of energy metabolism in adult offspring. PLoS One. 2012;7(6):e38795.

148 Motta-Teixeira LC, Machado-Nils AV, Battagello DS, Diniz GB, Andrade-Silva J, Silva S Jr, et al. The absence of maternal pineal melatonin rhythm during pregnancy and lactation impairs offspring physical growth, neurodevelopment, and behavior. Horm Behav. 2018 Sep;105:146-56.

149 Scheyer O, Rahman A, Hristov H, Berkowitz C, Isaacson RS, Diaz Brinton R, et al. Female sex and Alzheimer's risk: the menopause connection. J Prev Alzheimers Dis. 2018;5(4):225-30.

150 Jehan S, Jean-Louis G, Zizi F, Auguste E, Pandi-Perumal SR, Gupta R, et al. Sleep, melatonin, and the menopausal transition: what are the links? Sleep Sci. 2017 Jan-Mar; 10(1):11-8.
151 Sanchez-Mateos S, Alonso-Gonzalez C, Gonzalez A, Martinez-Campa CM, Mediavilla $\mathrm{MD}, \operatorname{Cos} \mathrm{S}$, et al. Melatonin and estradiol effects on food intake, body weight, and leptin in ovariectomized rats. Maturitas. 2007 Sep 20;58(1):91-101.

152 Baxi D, Singh PK, Vachhrajani K, Ramachandran AV. Melatonin supplementation therapy as a potent alternative to ERT in ovariectomized rats. Climacteric. 2012 Aug; 15(4):382-92.

153 Bellipanni G, DI Marzo F, Di Marzo A. Effects of melatonin in perimenopausal and menopausal women: our personal experience. Ann N Y Acad Sci. 2005 Dec;1057: 393-402.

154 Chojnacki C, Kaczka A, Gasiorowska A Fichna J, Chojnacki J, Brzozowski T. The effect of long-term melatonin supplementation on psychosomatic disorders in postmenopausal women. J Physiol Pharmacol. 2018 Apr;69(2).

155 Kripke DF, Kline LE, Shadan FF, Dawson A, Poceta JS, Elliott JA. Melatonin effects on luteinizing hormone in postmenopausal women: a pilot clinical trial NCT00288262. BMC Womens Health. 2006 May 16;6:8. 